\title{
Genetycznie uwarunkowany niedosłuch - perspektywy i możliwości diagnostyczne z wykorzystaniem sekwencjonowania nowej generacji
}

\section{Genetically determined hearing loss - perspectives and diagnostic capabilities of next-generation sequencing}

\author{
Urszula Lechowicz ${ }^{1}$, Agnieszka Pollak ${ }^{1}$, Piotr Stawiński ${ }^{1}$, Małgorzata Mueller-Malesińska ${ }^{1}$, \\ Rafał Płoski \\ ${ }^{1}$ Instytut Fizjologii i Patologii Słuchu, Światowe Centrum Słuchu, Zakład Genetyki, Kajetany \\ ${ }^{2}$ Warszawski Uniwersytet Medyczny, Zakład Genetyki Medycznej, Warszawa
}

Adres autora: Urszula Lechowicz, Światowe Centrum Słuchu, Zakład Genetyki, ul. Mokra 17, Kajetany, 05-830 Nadarzyn, e-mail: u.lechowicz@ifps.org.pl

\begin{abstract}
Streszczenie
Przyczyną około 50-60\% przypadków wystąpienia niedosłuchu są czynniki dziedziczne. Geny, w których zlokalizowane są warianty odpowiedzialne za wystąpienie niedosłuchu, najczęściej kodują białka występujące w uchu wewnętrznym. Za niedosłuch dziedziczony w sposób recesywny najczęściej odpowiedzialne są mutacje genu GJB2. Mutacje w innych genach, których produkty białkowe są bezpośrednio zaangażowane w proces słyszenia, mogą również skutkować wystąpieniem niedosłuchu. Do dziś opisano ok. 300 genów uczestniczących w procesie przetwarzania informacji słuchowej i nadal odkrywane są nowe. Efektywne poszukiwanie nieprawidłowości w ich strukturze wymaga stosowania najnowocześniejszych technik biologii molekularnej takich jak sekwencjonowanie nowej generacji. Dzięki nowatorskim technologiom o gigantycznej przepustowości możliwe są analizy całych genomów człowieka. Wysoka dokładność uzyskanych danych w połączeniu z wyrafinowaną analizą bioinformatyczną umożliwia wykrycie zmienności w sekwencji całego genomu. Otrzymane w wyniku sekwencjonowania dane poddawane są skomplikowanej obróbce bioinformatycznej pozwalającej finalnie na detekcję wariantów obecnych $\mathrm{w}$ badanym materiale. Wprowadzenie technologii genomowych jest przełomem w dziedzinie biologii medycznej. Ich wpływ na pogłębienie wiedzy na temat molekularnej fizjologii wielu procesów, w tym również procesu słyszenia oraz przyczyn niedosłuchu, jest rewolucyjny.
\end{abstract}

Słowa kluczowe: sekwencjonowanie nowej generacji • niedosłuch • genetyka

\section{Abstract}

Approximately $50-60 \%$ of cases of hearing loss are due to genetic factors. The genes responsible for the occurrence of hearing loss usually encode proteins located in the inner ear. Majority of patients with autosomal, recessive deafness harbour mutations in only one gene- GJB2. Mutations in other genes, which products are directly involved in the hearing process, may also result in hearing loss. To date, approximately 300 genes involved in the processing of auditory information has been described, and still the new one are discovered. Efficient search for variants in the gene structure requires the use of the most modern techniques of molecular biology, such as the next-generation sequencing. Owing to the innovative technologies of high throughput, whole genome analysis are possible. High accuracy of the obtained data combined with sophisticated bioinformatics analysis allows the detection of sequence variation in the whole genome. The data obtained from next generation sequencing are processed with advanced bioinformatics tools, which finally lead to detection of pathogenic variants in the analyzed material. The introduction of genomic technology is a breakthrough in the field of medical biology. Its influence on the broadening the biology knowledge and molecular physiology of many processes, including the process of hearing, is revolutionary.

Key words: next generation sequencing • hearing loss • genetics 


\section{Wprowadzenie}

Przyczyny wielu chorób, w tym również zaburzeń słuchu i mowy, są złożone i zwykle trudne do zidentyfikowania. Różnorodne czynniki genetyczne mogą być zarówno bezpośrednią przyczyną wystąpienia danej jednostki chorobowej, jak i wpływać na stopień nasilenia objawów. Obserwuje się wielorakie mechanizmy tych zjawisk - od prostych zależności mutacja-choroba, poprzez złożone interakcje kilku czy też kilkunastu genów odpowiedzialnych za wystąpienie chorób wielogenowych, aż do drobnych zmian modyfikujących przebieg choroby lub też obniżających bądź zwiększających ryzyko zachorowania.

Niedosłuch (ang. Hearing Loss, HL) to najczęstsze z zaburzeń zmysłów wykrywanych w krajach rozwiniętych przy urodzeniu (u 1-4 noworodków na 1000 żywych urodzeń objawia się obustronny zmysłowo-nerwowy niedosłuch na poziomie $40 \mathrm{~dB}$ lub głębszy). Do ukończenia piątego roku życia częstość występowania niedosłuchu wzrasta do 2,7 przypadków na 1000, pomiędzy piątym a osiemnastym rokiem życia odsetek wystąpienia uszkodzeń słuchu zwiększa się do 3,5 przypadków na $1000[1,2]$.

Niedosłuch można klasyfikować na wiele sposobów, biorąc pod uwagę różne czynniki, takie jak: etiologia, lokalizacja uszkodzenia słuchu, wiek wystąpienia, głębokość ubytku słuchu. Uwzględniając współistnienie innych objawów, rozróżnia się niedosłuch izolowany (bez innych objawów towarzyszących) oraz niedosłuch będący jednym $z$ objawów zespołów wad genetycznych lub niegenetycznych [3].

Około 50-60\% przyczyn wystąpienia niedosłuchu prelingwalnego należy upatrywać w znanych czynnikach dziedzicznych (genetycznych: mono- i poligenicznych), pozostałe przyczyny to: czynniki środowiskowe, a także niezidentyfikowane czynniki genetyczne [4-6].
Za jedną z najczęstszych przyczyn środowiskowych wystąpienia niedosłuchu uważa się wrodzoną cytomegalię $(\mathrm{CMV})$ [4] oraz inne infekcje wrodzone (różyczka, toksoplazmoza, ospa, kiła itp.). Kolejna grupa czynników ryzyka wystąpienia niedosłuchu prelingwalnego u dzieci to leki i substancje ototoksyczne przyjmowane przez matkę w trakcie ciąży (np. aminoglikozydy, cytostatyki, alkohol, rtęć). Ryzyko wystąpienia niedosłuchu wzrasta również w przypadku wystąpienia u matki chorób metabolicznych takich jak: cukrzyca, niedoczynność tarczycy, hiperlipidemia czy niewydolność nerek. Do kolejnej grupy niegenetycznych czynników ryzyka zalicza się czynniki okołoporodowe takie jak: wcześniactwo, niska masa urodzeniowa, niedotlenienie okołoporodowe, hiperbilirubinemia czy urazy okołoporodowe [7].

\section{Genetyczne przyczyny niedosłuchu}

Szacuje się, że spośród 30 000-50 000 ludzkich genów około 1\% (300-500 genów) bierze udział w procesie słyszenia [8]. Z problemem utraty słuchu boryka się ok. $70 \mathrm{mln} \mathrm{lu-}$ dzi na całym świecie. Blisko $50-60 \%$ z tych osób ma niedosłuch o podłożu genetycznym [9]. Około 50-80\% genetycznych przypadków niedosłuchu wrodzonego występuje jako jedyne schorzenie pacjenta (ang. Non Syndromic Hearing Loss, NSHL; niedosłuch izolowany - niesyndromiczny) $[6,10]$. Jeśli u pacjenta występują dodatkowe wady towarzyszące - a dzieje się tak u około $30 \%$ pacjentów - taki niedosłuch określa się mianem syndromicznego (ang. Syndromic Hearing Loss, SHL) [11]. Niektóre geny są przyczyną wystąpienia niedosłuchu zarówno izolowanego, jak i syndromicznego (CDH23, COL11A2, DDP1, DSPP, GJB2, GJB3, GJB6, MYO7A, MYH9, PCDH15, POU3F4) lub odpowiadają za wystąpienie dominującego, ale również recesywnego typu dziedziczenia (GJB2, GJB6, MYO6, MYO7A, TECTA, TMC1) [3]. Schematyczny podział przyczyn niedosłuchu prelingwalnego przedstawiono na rycinie 1 .

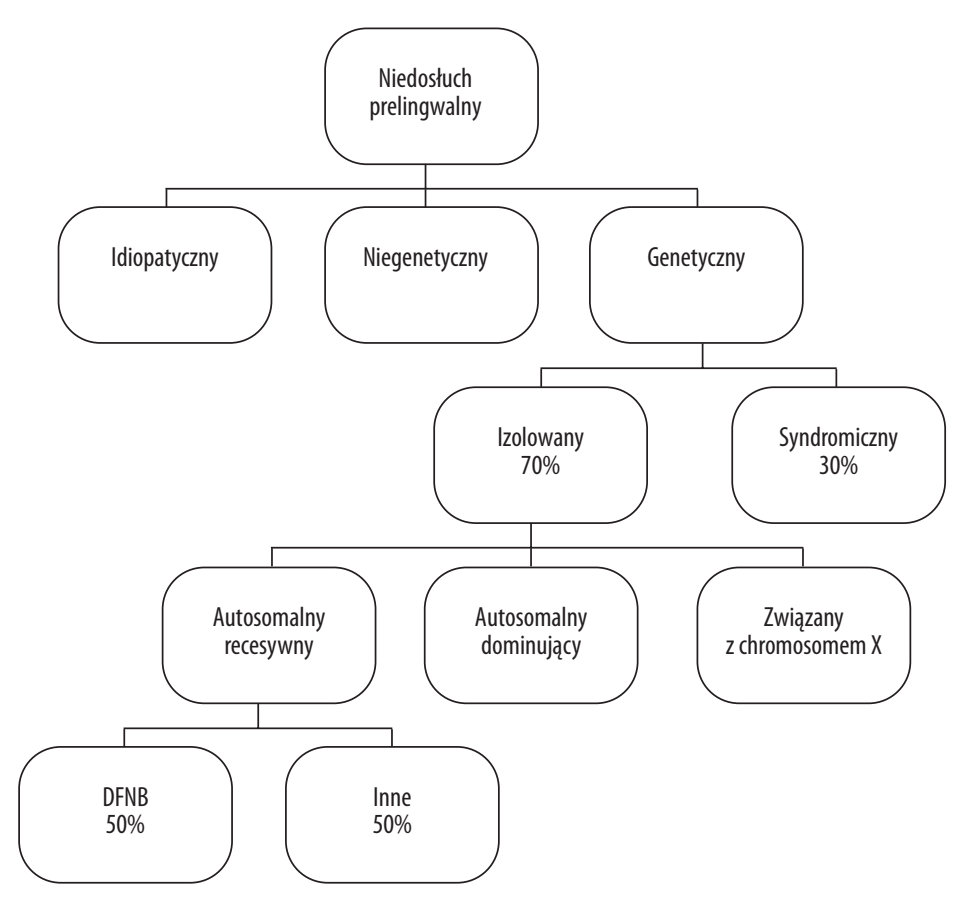

Rycina 1. Schematyczny podział niedosłuchu prelingwalnego

Figure 1. Schematic distribution of prelingual hearing loss 


\section{Niedosłuch niesyndromiczny (izolowany)}

Geny, w których zlokalizowane są mutacje odpowiedzialne za zaistnienie niedosłuchu izolowanego, najczęściej kodują białka występujące w uchu wewnętrznym. Geny te można podzielić na grupy z zależności od pełnionych funkcji: kodujące białka strukturalne (m.in. DIAPH, TECTA, COCH, COL11A1, COL11A2, COL2A1, OTOA, DSPP, USH1C, $D S P P)$, zaangażowane w transport jonów (GJA1, GJB1, GJB2, GJB3, GJB6, KCNQ4, KCNQ1), kodujące czynniki transkrypcyjne i regulatorowe (POU3F4, POU4F3, EYA1, EYA4, PAX3) i inne [12].

Niedosłuch izolowany zazwyczaj spowodowany jest mutacjami w jednym genie i może być dziedziczony w sposób autosomalny recesywny (Autosomal Recessive, AR; ok. 80\% przypadków), autosomalny dominujący (Autosomal Dominant, $\mathrm{AD}$; ok. $20 \%$ przypadków) oraz sprzężony z płcią lub mitochondrialny (ok. 1\% przypadków) [13]. Typ dziedziczenia koreluje z czasem wystąpienia niedosłuchu: przy typie dziedziczenia autosomalnym recesywnym $\mathrm{w}$ większości przypadków obserwowany jest niedosłuch prelingwalny, niepostępujący, dla dziedziczenia dominującego obserwuje się wystąpienie niedosłuchu postlingwalnego o charakterze postępującym. Niedosłuch mitochondrialny również najczęściej występuje w okresie postlingwalnym i jest postępujący [14].

Do dnia dzisiejszego zmapowano i opisano ponad 150 loci powiązanych z niedosłuchem izolowanym. Zidentyfikowano ponad 70 genów, w których uszkodzenia odpowiedzialne są za wystąpienie niedosłuchu, w tym 42 dziedziczone w sposób autosomalny recesywny i 27 w sposób autosomalny dominujący (http://hereditaryhearingloss.org/). Każdemu nowemu zmapowanemu locus nadawany jest numer, zgodny z kolejnością odkrycia, oraz oznaczenie sposobu dziedziczenia: DFNB (autosomalne recesywne), DFNA (autosomalne dominujące), DFN (sprzężone $\mathrm{z}$ chromosomem $\mathrm{X}$ ), DFNM (dla genów modyfikujących ekspresję). Gdy gen zostanie zidentyfikowany, zwykle jego nazwa zastępuje nomenklaturę DFN [1]. Dla pozostałych loci poszukiwane są geny, a ich pula sukcesywnie się zwiększa. Identyfikacja wszystkich genów, w których nieprawidłowości skutkują wystąpieniem niedosłuchu, pozwoli lepiej zrozumieć proces przekazywania i percepcji informacji słuchowej.

Z uwagi na fakt, że najczęstsza forma niedosłuchu uwarunkowanego genetycznie dziedziczy się w sposób recesywny, innymi słowy - rodzice i dalsza rodzina pacjenta to nosiciele „uszkodzonego" genu niewykazujący żadnych objawów (słyszący prawidłowo), w znaczącej części przypadków prześledzenie historii choroby w rodzinie jest wyjątkowo trudne. W takich sytuacjach jedynym sposobem pomagającym ustalić podłoże niedosłuchu są specjalistyczne badania molekularne. Niesyndromiczny niedosłuch o autosomalnym recesywnym typie dziedziczenia (ARNSHL) zazwyczaj jest wrodzony, o znacznym stopniu nasilenia, stabilny, wpływający na wszystkie częstotliwości [15]. Najczęściej za wystąpienie ARNSHL odpowiadają geny: GJB2, SLC26A4, MYO15A, OTOF, CDH23 oraz TMC1. W większości populacji kaukaskich najczęstszą mutacją odpowiedzialną za niedosłuch autosomalny recesywny jest delecja guaniny w pozycji 35 (35delG) sekwencji kodującej genu koneksyny 26 (GJB2), DFNB1. Częstość tej mutacji w populacji polskiej wynosi około
$4 \%$, jest to więc jedna $\mathrm{z}$ najczęstszych mutacji genetycznych w naszej populacji [16].

Z nielicznymi wyjątkami, izolowany autosomalny dominujący niedosłuch (ADNSHL) w porównaniu z ARNSHL charakteryzuje się mniejszym stopniem ubytku słuchu, rozpoczyna się w drugiej lub w trzeciej dekadzie życia. Dla ADNSHL zazwyczaj obserwuje się wystąpienie niedosłuchu postlingwalnego o charakterze postępującym, zaczynającym się zarówno na wysokich (DFNA2, 5, 7, 9, 16, and 17), jak i średnich oraz mieszanych tonach (DFNA3, $4,8 / 12,10,11,13)$. Najczęściej opisywane mutacje dla tego typu niedosłuchu dotyczą genów: WFS1, KCNQ4, COCH, GJB2 [17-23].

Niedosłuch spowodowany uszkodzeniami genów, dla których opisano sposób dziedziczenia sprzężony z chromosomem X lub matczyny typ dziedziczenia (mutacje w mitochondrialnym DNA), jest stosunkowo rzadko występujący, niemniej jednak istotny z punktu widzenia poradnictwa i postępowania terapeutycznego.

Uważa się, iż niedosłuch związany z mutacjami w mtDNA jest zazwyczaj obustronny, symetryczny, postępujący w czasie, początkowo występujący tylko w obrębie wysokich tonów, a następnie zajmujący również inne częstotliwości. „Mitochondrialna” głuchota może współistnieć z zawrotami głowy i szumami usznymi. Wystąpienie pierwszych objawów może mieć miejsce zarówno w dzieciństwie, jak i w wieku dorosłym, średnio zakłada się wystąpienie pierwszych objawów w wieku ok. 5 rż., choć zdarzają się również przypadki niedosłuchu mitochondrialnego pojawiającego się po 65 roku życia $[24,25]$. W populacji kaukaskiej ok. 5\% postlingwalnych, izolowanych, niedosłuchów spowodowane jest przez znane mutacje w mitochondrialnym DNA (mtDNA). W populacji polskiej obserwuje się stosunkowo wysoki odsetek niedosłuchu powiązanego z wystąpieniem mutacji m.3243A>G [26]. Najczęściej badanymi w kontekście niedosłuchu genami mitochondrialnymi są fragmenty kodujące rybosomalne RNA (głównie 12SrRNA) oraz transportujące RNA (tRNA). Jednak mutacje $w$ innych regionach mtDNA mogą również mieć wpływ na powstanie niedosłuchu.

\section{Niedosłuch syndromiczny}

Do dnia dzisiejszego opisano ponad 400 zespołów wad ze współistniejącym niedosłuchem. Zespoły te charakteryzują się różnym typem dziedziczenia: autosomalnym recesywnym (75-80\%), autosomalnym dominującym (10-20\%), sprzężonym z płcią (1-5\%), mitochondrialnym (0-2\%) [27]. Najczęściej opisywanymi zespołami ze współistniejącym niedosłuchem są: zespół Pendreda, zespół skrzelowo-uszno-nerkowy (BOR), zespół Waardenburga, zespół Ushera, zespół Alporta, zespół Jervella i Lange-Nielsena (zespół wydłużonego odcinka QT), zespół Treachera Collinsa, zespół Sticklera (dziedziczna, postępująca artro-oftalmopatia) oraz zespoły związane z zaburzeniami chromosomalnymi: zespół Downa, zespół Turnera [3].

\section{Technologie sekwencjonowania nowej generacji}

W przeważającej liczbie przypadków za niedosłuch dziedziczony w sposób recesywny odpowiedzialne są mutacje 
genu GJB2. Nieprawidłowości w innych genach, których produkty (białka) są bezpośrednio zaangażowane w proces słyszenia, mogą również powodować niedosłuch. Takie zmiany w zależności od tego, w jakim genie są zlokalizowane, mogą powodować niedosłuch o różnym stopniu nasilenia i czasie wystąpienia oraz mogą determinować progresję lub jej brak. Obserwuje się charakterystyczne „Wzory” zmian dla poszczególnych grup etnicznych [6]. Dlatego niezwykle ważne jest prowadzenie szeroko zakrojonych badań naukowych nad patogenezą niedosłuchu dla różnych populacji. Ponieważ do dziś poznano ok. 300 genów uczestniczących w procesie słyszenia i nadal odkrywane są nowe, efektywne poszukiwanie nieprawidłowości w ich strukturze wymaga stosowania najnowocześniejszych technik biologii molekularnej, takich jak sekwencjonowanie nowej generacji (Next Generation Sequencing, NGS). Dzięki innowacyjnym technikom o tak niespotykanej przepustowości możliwe są analizy całych genomów człowieka. Wysoka dokładność uzyskanych danych w połączeniu $\mathrm{z}$ wyrafinowaną analizą bioinformatyczną umożliwia wykrycie zmienności w sekwencji całego genomu. Te wyjątkowe metody zostały wdrożone do badań naukowych w Zakładzie Genetyki Instytutu Fizjologii i Patologii Słuchu.

Technologia sekwencjonowania Sangera, po raz pierwszy opisana w 1977 r., pozostawała przez ponad 30 lat metodą $\mathrm{z}$ wyboru zarówno w naukowych badaniach genetycznych, jak i diagnostycznych [28]. Z użyciem tej technologii i automatycznych sekwenatorów w 2001 r. zakończono projekt sekwencjonowania ludzkiego genomu (Human Genome Project, HGP). Ukończenie HGP spowodowało wzrost zapotrzebowania na nowe technologie szybkiego i taniego sekwencjonowania zarówno dla diagnostyki klinicznej, jak i naukowych badań genetycznych. Sekwencjonowanie nowej generacji (NGS), zwane także masywnym paralelnym sekwencjonowaniem (MPS), zostało opracowane w ciągu ostatnich pięciu lat, aby sprostać tym potrzebom. Chociaż istnieje kilka platform NGS opartych na różnych technologiach, łączy je następująca charakterystyka: wysoka wydajność, duża głębokość sekwencjonowania i stosunkowo krótkie odczyty sekwencji. Najbardziej zaawansowany automatyczny sekwenator odczytuje sekwencje z wydajnością 120000 bp (par zasad) na dobę. Szacunkowy koszt odczytu $1 \mathrm{mln}$ par zasad (1 Mb) to 12000 PLN [29]. Sekwencjonowanie pojedynczego ludzkiego genomu o wielkości 3,2 mld par zasad (3,2 Gb) za pomocą takiego sekwenatora zajęłoby 73 lata i kosztowało ok. 600000 PLN. W przeciwieństwie do tego, wydajność pojedynczego urządzenia NGS na dzień dzisiejszy jest większa niż 30 Gb na 24 godziny i kosztuje ok. 6 PLN za Mb, co oznacza, że ludzki genom można sekwencjonować w jeden dzień za ułamek kosztów w porównaniu $\mathrm{z}$ automatycznym sekwencjonowaniem metodą Sangera. Obliczenia te nie uwzględniają analizy bioinformatycznej, bez której opracowanie danych NGS nie jest możliwe. Technologia NGS oparta na ogromnej ilości odczytów pojedynczej sekwencji charakteryzuje się zwiększonym odsetkiem błędów w porównaniu z sekwencjonowaniem Sangera. Odsetek ten jest zależny od rodzaju urządzenia i wynosi od $0,1 \%$ do $2 \%$ [30]. Aby ograniczyć poziom błędów, nici DNA sekwencjonowane są wielokrotnie do osiągnięcia odpowiedniego "pokrycia” lub „głębokości odczytu”, gwarantującej pewność, że wariant nie jest artefaktem.
Technologia NGS umożliwia nie tylko odczytanie pełniej sekwencji genomu, lecz także analizy na mniejszą skalę, m.in. sekwencjonowanie eksomowe (analiza sekwencji eksonów wszystkich genów, czyli ich fragmentów kodujących, Exome Enrichment, EE) oraz kierunkowe wychwytywanie zestawu konkretnych genów (ograniczenie analizy do badania tylko znanych genów, których warianty są przyczyną konkretnego schorzenia, Targeted Enrichment, TE).

Sekwencjonowanie eksomowe jest technologią pośrednią między kierunkowym wychwytywaniem konkretnych genów a sekwencjonowaniem całego genomu. Analiza sekwencyjna całego eksomu jest bardziej kosztowna niż nakierowana na małą ilość genów, ale umożliwia zarówno poszukiwanie zmian patogennych w znanych genach, jak i odkrywanie nowych genów powiązanych z analizowanymi szlakami. Warto jednak zauważyć, że w przypadku tej metody nie są analizowane sekwencje niekodujące, które mogą zawierać elementy regulatorowe istotne dla prawidłowego funkcjonowania genów, aczkolwiek technologia sekwencjonowania eksomów jest uważana za skuteczną strategię odkrywania nowych genów, ponieważ większość zmian patogennych spowodowana jest mutacjami regionów kodujących białka [31-34]. Z użyciem tej technologii odkryto osiem nowych genów powiązanych $\mathrm{z}$ niedosłuchem (tabela 1).

Potężna ilość danych, generowanych przy użyciu platform sekwencjonowania nowej generacji, stała się przyczyną zapotrzebowania na wyrafinowane narzędzia bioinformatyczne umożliwiające analizy miliardów krótkich odczytów i mapowania ich do genomów referencyjnych. Niezwykle ważna jest również ocena jakości odczytów [43]. Otrzymane w wyniku sekwencjonowania dane poddawane są skomplikowanej obróbce bioinformatycznej, umożliwiającej finalnie detekcję wariantów obecnych w badanym materiale. Wykorzystywane są w tym celu zaawansowane narzędzia bioinformatyczne, złożone w ścieżkę procesowania danych zgodną z zaleceniami Broad Institute. W procedurze obróbki danych wykorzystywane są między innymi programy BWA oraz narzędzia dostępne w środowisku Genome Analysis Toolkit [43]. Ostatnim krokiem jest anotacja wariantów opisem ich biologicznej funkcjonalności, dostarczająca informacji na temat każdej zidentyfikowanej zmiany. Na podstawie anotacji można ocenić, czy analizowana zmiana leży w obrębie genu, czy i jak wpływa na zmianę białka. Ostatecznie w wyniku sekwencjonowania wykrywane są warianty odróżniające badaną próbkę od genomu referencyjnego, które poddane następnie analizie eksperckiej pozwalają na detekcję genetycznego podłoża obserwowanego fenotypu.

Właściwa anotacja i dokonywana na jej podstawie ekspercka selekcja wariantów jest konieczna w celu efektywnej identyfikacji poszukiwanego wariantu. Zwykle wynikiem sekwencjonowania eksomowego jest detekcja około 60000 wariantów obecnych w próbce. Analiza ekspercka takiej ilości danych bez użycia programów komputerowych jest niezwykle czasochłonna, dlatego filtruje się otrzymaną listę w celu wyszczególnienia wariantów o najwyższym prawdopodobieństwie patogenności, eliminując warianty częste w populacji (z wykorzystaniem informacji o częstości z publicznych baz danych wariantów, między innymi pochodzących z projektów Exome Sequencing 
Tabela 1. Nowo odkryte geny głuchoty z użyciem technologii sekwencjonowania nowej generacji

Table 1. The newly discovered deafness genes with the usage of next-generation sequencing technologies

\begin{tabular}{|c|c|c|c|c|c|c|}
\hline$\stackrel{\text { Typ }}{\text { niedosłuchu }}$ & Locus/zespół & Gen & $\begin{array}{l}\text { Liczba } \\
\text { rodzin }\end{array}$ & $\begin{array}{l}\text { Analizowane } \\
\text { regiony }\end{array}$ & $\begin{array}{l}\text { Platforma } \\
\text { NGS }\end{array}$ & Piśmiennictwo \\
\hline ARNSHL & DFNB79 & TPRN & 4 & $\begin{array}{c}\text { celowane } \\
\text { wzbogacanie }\end{array}$ & Roche454 & {$[35]$} \\
\hline ARNSHL & DFNB82 & GPSM2 & 1 & eksom & Illumina & {$[36]$} \\
\hline ARNSHL & DFNA4 & CEACAM16 & 1 & eksom & SOLiD & [37] \\
\hline XLNSHL & DFNX4 & SMPX & 2 & chromosomX & Illumina & [38] \\
\hline Syndromiczny & zespół Perrault & HSD17B4 & 1 & eksom & Illumina & [39] \\
\hline Syndromiczny & zespół Perrault & HARS2 & 1 & $\begin{array}{c}\text { celowane } \\
\text { wzbogacanie }\end{array}$ & Illumina & [40] \\
\hline Syndromiczny & $\begin{array}{c}\text { zespół Carnevale, } \\
\text { zespół Malpuech, } \\
\text { zespół OSA, } \\
\text { zespół Michels }\end{array}$ & MASP1 & 2 & eksom & Illumina & [41] \\
\hline Syndromiczny & $\begin{array}{c}\text { dziedzina } \\
\text { neuropatia, } \\
\text { demencja } \\
\text { i niedosłuch }\end{array}$ & DNMT1 & 4 & eksom & $\begin{array}{l}\text { Illumina; } \\
\text { Roche454 }\end{array}$ & {$[42]$} \\
\hline
\end{tabular}

ARNSHL - izolowany, autosomalny recesywny niedosłuch; ADNSHL - izolowany, autosomalny dominujący niedosłuch; XLNSHL - izolowany niedosłuch sprzężony $z$ chromosomem $X$.

ARNSHL - autosomal recessive non-syndromic hearing loss; ADNSHL - autosomal dominant non-syndromic hearing loss; XLNSHL - non-syndromic hearing loss linked to the $\mathrm{X}$ chromosome.

Project (http://evs.gs.washington.edu/EVS/), 1000 genomes Project (2012) [44], a także baz danych wariantów dbSNP [45]. Eliminacja częstych wariantów z listy rozważanych umożliwia ograniczenie jej wielkości do 6000. Dalsza eliminacja zmian synonimicznych pozwala zwykle na redukcję ich liczby do około 1000. Kolejne kroki w procesie detekcji wariantów opierają się jedynie na doświadczeniu i wiedzy eksperckiej osoby analizującej, która potrafiąc nadać biologiczne znaczenie poszczególnym wariantom na podstawie ich lokalizacji i rodzaju, jest w stanie zidentyfikować wariant potencjalnie patogenny, będący przyczyną obserwowanego fenotypu.

\section{Sekwencjonowanie nowej generacji - doświadczenia własne}

W Zakładzie Genetyki Światowego Centrum Słuchu od roku prowadzone są badania naukowe $\mathrm{z}$ wykorzystaniem innowacyjnej technologii sekwencjonowania nowej generacji. Analizy wykonywane są z użyciem platformy Illumina HiSeq1500. Nadrzędnym celem prowadzonych badań jest detekcja genetycznych przyczyn wystąpienia niedosłuchu, innych niż mutacje genu GJB2, wśród pacjentów Instytutu Fizjologii i Patologii Słuchu. Poszukiwane są zarówno znane mutacje $\mathrm{w}$ genach powiązanych $\mathrm{z}$ procesem słyszenia, jak i zmiany w genach niepowiązanych do tej pory $\mathrm{z}$ procesem utraty słuchu. $\mathrm{W}$ tym celu wdrożona została procedurę sekwencjonowania eksomu oraz genomu mitochondrialnego.

Potwierdzeniem skuteczności technologii NGS jest wykrycie między innymi homozygotycznej mutacji p.V138F genu SLC26A4 (pendryny) u pacjentki z głębokim, rodzinnym niedosłuchem. Analiza rodowodu sugerowała recesywny sposób dziedziczenia wady. Na materiale genetycznym od pacjentki wykonano sekwencjonowanie eksomowe. $\mathrm{Na}-$ stępnie przeprowadzono analizę bioinformatyczną, mapowanie do genomu referencyjnego, filtrowanie i anotację wariantów. Pacjentka podpisała świadomą zgodę na uczestnictwo w badaniach. Zastosowane procedury uzyskały zgodę Komisji Bioetycznej przy Instytucie Fizjologii i Patologii Słuchu.

Analiza anotacji mutacji p.V138F genu SLC26A4 przedstawionych w tabeli 2 pozwala ocenić hipotetyczną patogenność wariantu (dane w kolumnach: AVSIFT, LJB PhyloP, LJB_PhyloP_Pred, LJB_SIFT, LJB_SIFT_Pred, LJB_PolyPhen2, LJB_LRT_Pred, LJB_MutationTaster, LJB_MutationTaster_Pred, LJB_PolyPhen2_Pred, LJB_ LRT, LJB_LRT_Pred, LJB_MutationTaster, LJB_MutationTaster_Pred), jego częstość występowania w populacyjnych bazach danych (dane w kolumnach: ESP6500_ALL, 1000g2012feb_ALL, 1000g_EUR, esp6500si_ea), jakość odczytów NGS (dane w kolumnach: Quality, Filter) oraz powiązanie $\mathrm{z}$ chorobą, o ile wariant został wcześniej opisany (dane w kolumnie: Disease point). Obraz wariantu p.V138F, pokrycie i lokalizację eksonową przedstawiono na rycinie 2 .

Wariant V138F genu SLC26A4 jest uznany za patogenny, powiązany z wystąpieniem zespołu Pandreda. Mutacja zlokalizowana jest w 3 domenie przezbłonowej białka pendryny i skutkuje zmianą konserwowanej waliny na fenyloalaninę. Biologiczną konsekwencją tej zmiany jest zaburzenie transportu białka do błony komórkowej [46,47]. 
Tabela 2. Anotacje mutacji p.V138F genu SLC26A4

Table 2. Annotations of p.V138F mutation in SLC26A4 gene

\begin{tabular}{|c|c|c|c|c|c|c|c|c|c|c|}
\hline Identifier & Gene & Func & ExonicFunc & AAChange & VcfData & $\begin{array}{l}\text { Homo- } \\
\text { zygote }\end{array}$ & $\begin{array}{c}\text { ESP6500_ } \\
\text { ALL }\end{array}$ & $\begin{array}{c}1000 \mathrm{~g} \\
2012 \\
\text { feb_ALL }\end{array}$ & Quality & Filter \\
\hline $\begin{array}{c}\text { chr7: } \\
\text { 107312690- } \\
\text { G/T }\end{array}$ & $\begin{array}{c}\mathrm{SLC} \\
26 \mathrm{~A} 4\end{array}$ & exonic & $\begin{array}{l}\text { nonsy- } \\
\text { nonymous } \\
\text { SNV }\end{array}$ & $\begin{array}{l}\text { NM_000441: } \\
\text { c.G412T: p.V138F }\end{array}$ & $\begin{array}{c}1 / 1: 1,50: 99: \\
1588,147,0\end{array}$ & tak & 0,000077 & 0 & 1559,77 & PASS \\
\hline start & xend & ref & obs & Conserved & AVSIFT & $\begin{array}{l}\text { LJB } \\
\text { PhyloP }\end{array}$ & $\begin{array}{l}\text { LJB_- } \\
\text { PhyloP_- } \\
\text { Pred }\end{array}$ & LJB_SIFT & $\underset{\text { Pred }}{\text { LJB_SIFT_ }}$ & $\begin{array}{c}\text { LJB_Poly } \\
\text { Phen2 }\end{array}$ \\
\hline $1,07 E+08$ & $\begin{array}{l}1,07 \mathrm{E} \\
+08\end{array}$ & G & $\mathrm{T}$ & $\begin{array}{l}\text { 608; Name } \\
=\text { lod }=396\end{array}$ & 0 & $\begin{array}{c}0,999 \\
474\end{array}$ & C & 1 & D & 0,985 \\
\hline $\begin{array}{l}\text { LJB_ } \\
\text { PolyPhen2_ } \\
\text { Pred }\end{array}$ & $\begin{array}{l}\text { LJB } \\
\text { LRT }\end{array}$ & $\begin{array}{c}\text { LJB_LRT_ } \\
\text { Pred }\end{array}$ & $\begin{array}{l}\text { LJB } \\
\text { Mutation- } \\
\text { Taster }\end{array}$ & $\begin{array}{l}\text { LJB } \\
\begin{array}{c}\text { MutationTaster_ } \\
\text { Pred }\end{array}\end{array}$ & LJB_GERP++ & Depth & $\operatorname{cg} 69$ & 1000 g_EUR & $\begin{array}{l}\text { esp6500 } \\
\text { si_ea }\end{array}$ & $\begin{array}{c}\text { disease_ } \\
\text { point }\end{array}$ \\
\hline D & $\begin{array}{c}0,999 \\
964\end{array}$ & D & 0,99372 & D & 4,99 & 51 & 0 & 0 & 0 & $\begin{array}{l}\text { Pendred } \\
\text { syndrome }\end{array}$ \\
\hline
\end{tabular}

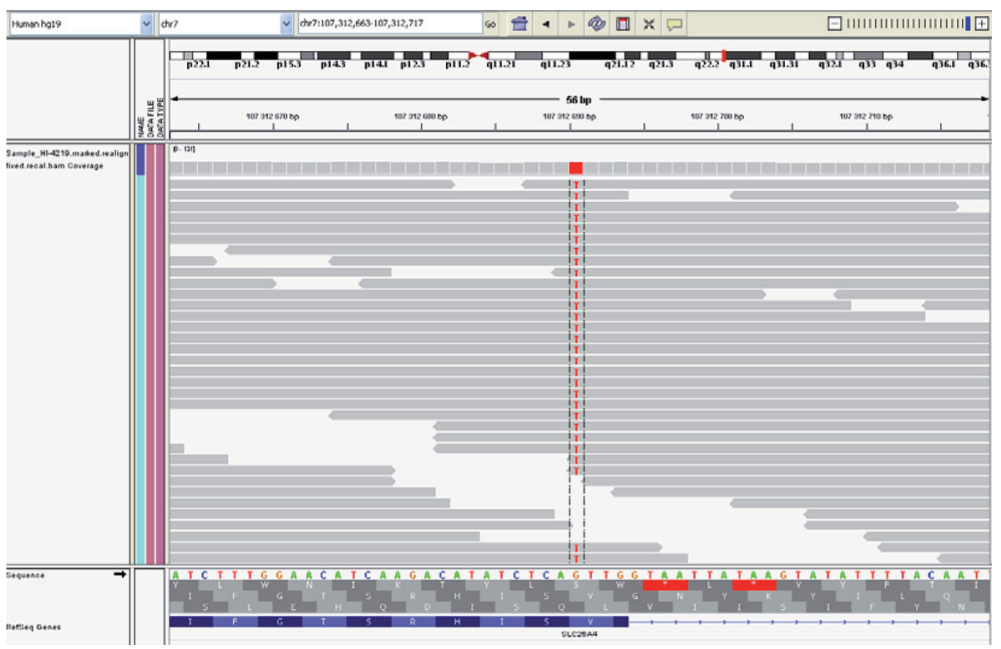

Rycina 2. Obraz analizy wariantu V138F genu SLC26A4 w programie IGV

Figure 2. Image of the $\mathrm{V} 138 \mathrm{~F}$ variant in SLC26A4 gene in the IGV

\section{Diagnostyczne badania genetyczne w niedosłuchu $z$ użyciem technologii genomowych}

Idealny test genetyczny jest wysoko czuły, specyficzny i precyzyjny. Dodatkowo w przypadku testów diagnostycznych istotny jest ich stosunkowo niski koszt, choć należy pamiętać, że testy genetyczne w większości przypadków wykonuje się raz w życiu pacjenta, więc cena takiego testu może być wyższa niż innych, rutynowych diagnostycznych badań laboratoryjnych, wykonywanych wielokrotnie. Do tej pory żaden test genetyczny przeznaczony do analizy podłoża genetycznie uwarunkowanego niedosłuchu nie osiągnął w pełni tych założeń. Natomiast $\mathrm{z}$ wykorzystaniem nowych technologii genomowych można przeprowadzić kompleksowe badania genetyczne dla pacjentów z niedosłuchem. Optymalnym rozwiązaniem wydaje się być konstrukcja celowanych testów obejmujących kilkanaście genów, a nie jedynie wybranych zmian patogennych, w których warianty powodują niedosłuch stosunkowo często dla danej populacji. Test taki może powstać jedynie na podstawie szerokich analiz typu sekwencjonowania genomowego lub eksomowego na reprezentatywnej grupie pacjentów.

\section{Podsumowanie}

Potwierdzenie istnienia mechanizmu genetycznej indukcji niedosłuchu oraz identyfikacja czynników mogących wpływać na jego wystąpienie są niezwykle istotne przy opracowywaniu zarówno nowatorskich terapii leczniczych, jak i badań prowadzących do stworzenia terapii genowej. Na podstawie kompleksowej analizy różnic genetycznych oraz wpływu środowiskowych czynników ryzyka możliwe jest przygotowanie innowacyjnych algorytmów medycznych pozwalających na uniknięcie ryzyka pogłębienia niedosłuchu.

Wprowadzenie technologii genomowych jest przełomem w dziedzinie biologii medycznej. Ich wpływ na poszerzenie wiedzy na temat molekularnej fizjologii wielu procesów, w tym również procesu słyszenia oraz przyczyn niedosłuchu, jest rewolucyjny. Diagnostyka niedosłuchu niezwiązanego z mutacjami genu GJB2 i GJB6 jest bardzo skomplikowana, czasochłonna i kosztowna z uwagi na jego heterogenność genetyczną. Wprowadzenie platform sekwencjonowania nowej generacji, początkowo do celów naukowych, a następnie przygotowanie szeroko 
zakrojonych testów diagnostycznych opartych na tej technologii, to przełom, który bezpośrednio przełoży się na lepszą opiekę nad pacjentem, dzięki szybszej i bardziej precyzyjnej diagnozie.

\section{Podziękowania}

Badania były dofinansowane z grantów NCN: 2012/05/N/ NZ5/02629 oraz 2011/03/D/NZ5/05592.

\section{Piśmiennictwo:}

1. Morton CC, Nance WE. Newborn hearing screening - a silent revolution. N Engl J Med, 2006; 354(20): 2151-64.

2. Smith RJ, Bale JF Jr, White KR. Sensorineural hearing loss in children. Lancet, 2005; 365(9462): 879-90.

3. Kochhar A, Hildebrand MS, Smith RJ. Clinical aspects of hereditary hearing loss. Genet Med, 2007; 9(7): 393-408.

4. Kenneson A, Cannon MJ. Review and meta-analysis of the epidemiology of congenital cytomegalovirus (CMV) infection. Rev Med Virol, 2007; 17(4): 253-76.

5. Grundfast KM, Siparsky N, Chuong D. Genetics and molecular biology of deafness. Update. Otolaryngol Clin North Am, 2000; 33(6): 1367-94.

6. Smith RJ, Hone S. Genetic screening for deafness. Pediatr Clin North Am, 2003; 50(2): 315-29.

7. Beswick R, Driscoll C, Kei J. Monitoring for postnatal hearing loss using risk factors: a systematic literature review. Ear Hear, 2012; 33(6): 745-56.

8. Friedman TB, Griffith AJ. Human nonsyndromic sensorineural deafness. Annu Rev Genomics Hum Genet., 2003; 4: 341-402.

9. Tekin M, Arnos KS, Pandya A. Advances in hereditary deafness. Lancet, 2001; 358(9287): 1082-90.

10. Petersen MB. Non-syndromic autosomal-dominant deafness. Clin Genet, 2002; 62(1): 1-13.

11. Van Camp G, Willems PJ, Smith RJ. Nonsyndromic hearing impairment: unparalleled heterogeneity. Am J Hum Genet., 1997; 60(4): 758-64.

12. Hilgert N, Smith RJ, Van Camp G. Function and expression pattern of nonsyndromic deafness genes. Curr Mol Med, 2009; 9(5): 546-64.

13. Marion RW. The genetic anatomy of hearing. A clinician's view. Ann NY Acad Sci. 1991; 630: 32-37.

14. Cryns K, Van Camp G. Deafness genes and their diagnostic applications. Audiol Neurootol., 2004; 9(1): 2-22.

15. Hilgert N, Smith RJ, Van Camp G. Forty-six genes causing nonsyndromic hearing impairment: which ones should be analyzed in DNA diagnostics? Mutat Res, 2009; 681(2-3): 189-96.

16. Mueller-Malesinska M, Nowak M, Skarzynski H, Ploski R, Waligora J, Korniszewski L. Epidemiology of 35delG mutation in GJB2 gene in a Polish population. Journal of Audiological Medicine, 2001; 10: 136-141

17. Lynch ED, León PE. Non-syndromic dominant DFNA1. Adv Otorhinolaryngol, 2000; 56: 60-67.

18. van Camp G, Coucke P, Balemans W, van Velzen D, van de Bilt C, van Laer Li i wsp. Localization of a gene for non-syndromic hearing loss (DFNA5) to chromosome 7p15. Hum Mol Genet, 1995; 4(11): 2159-63.

19. Pfister M, Thiele H, Van Camp G, Fransen E, Apaydin F, Aydin O i wsp. A genotype-phenotype correlation with gender-effect for hearing impairment caused by TECTA mutations. Cell Physiol Biochem, 2004; 14(4-6): 369-76.

20. Kamarinos M, McGill J, Lynch M, Dahl H. Identification of a novel $\mathrm{COCH}$ mutation, I109N, highlights the similar clinical features observed in DFNA9 families. Hum Mutat., 2001; 17(4): 351. Erratum in: Hum Mutat, 2001; 18(6): 547-48.
21. Fagerheim T, Nilssen O, Raeymaekers P, Brox V, Moum T, Elverland $\mathrm{HH}$ i wsp. Identification of a new locus for autosomal dominant non-syndromic hearing impairment (DFNA7) in a large Norwegian family. Hum Mol Genet, 1996; 5(8): 1187-91.

22. Manolis EN, Yandavi N, Nadol JB Jr, Eavey RD, McKenna M, Rosenbaum S i wsp. A gene for non-syndromic autosomal dominant progressive postlingual sensorineural hearing loss maps to chromosome 14q12-13. Hum Mol Genet, 1996; 5(7): 1047-50.

23. Coucke P, Van Camp G, Djoyodiharjo B, Smith SD, Frants RR, Padberg GW i wsp. Linkage of autosomal dominant hearing loss to the short arm of chromosome 1 in two families. N Engl J Med, 1994; 331(7): 425-31.

24. Kokotas H, Petersen MB, Willems PJ. Mitochondrial deafness. Clin Genet, 2007; 71(5): 379-91.

25. Guan MX. Molecular pathogenetic mechanism of maternally inherited deafness. Ann NY Acad Sci, 2004; 1011: 259-71.

26. Iwanicka-Pronicka K, Pollak A, Skórka A, Lechowicz U, Pajdowska M, Furmanek M i wsp. Postlingual hearing loss as a mitochondrial 3243A $>\mathrm{G}$ mutation phenotype. PLoS One, 2012; 7(10): e44054.

27. Smith SD. Overview of genetic auditory syndromes. J Am Acad Audiol, 1995; 6(1): 1-14.

28. Sanger F, Nicklen S, Coulson AR. DNA sequencing with chain-terminating inhibitors. Proc Natl Acad Sci USA, 1977; 74(12): 5463-67.

29. Metzker ML. Sequencing technologies - the next generation. Nat Rev Genet, 2010; 11(1): 31-46.

30. Glenn TC. Field guide to next-generation DNA sequencers. Mol Ecol Resour, 2011; 11(5): 759-69.

31. Chen JM, Férec C, Cooper DN. Revealing the human mutome. Clin Genet, 2010; 78(4): 310-20.

32. Ng SB, Buckingham KJ, Lee C, Bigham AW, Tabor HK, Dent $\mathrm{KM}$ i wsp. Exome sequencing identifies the cause of a mendelian disorder. Nat Genet, 2010; 42(1): 30-35.

33. Ng SB, Turner EH, Robertson PD, Flygare SD, Bigham AW, Lee $\mathrm{C}$ i wsp. Targeted capture and massively parallel sequencing of 12 human exomes. Nature, 2009; 461(7261): 272-76.

34. Teer JK, Mullikin JC. Exome sequencing: the sweet spot before whole genomes. Hum Mol Genet, 2010; 19(R2): R145-51.

35. Rehman AU, Morell RJ, Belyantseva IA, Khan SY, Boger ET, Shahzad M, i wsp. Targeted capture and next-generation sequencing identifies C9orf75, encoding taperin, as the mutated gene in nonsyndromic deafness DFNB79. Am J Hum Genet, 2010; 86(3): 378-88.

36. Walsh T, Shahin H, Elkan-Miller T, Lee MK, Thornton AM, Roeb W i wsp. Whole exome sequencing and homozygosity mapping identify mutation in the cell polarity protein GPSM2 as the cause of nonsyndromic hearing loss DFNB82. Am J Hum Genet, 2010; 87(1): 90-94.

37. Zheng J, Miller KK, Yang T, Hildebrand MS, Shearer AE, DeLuca AP i wsp. Carcinoembryonic antigen-related cell adhesion molecule 16 interacts with alpha-tectorin and is mutated in autosomal dominant hearing loss (DFNA4). Proc Natl Acad Sci USA, 2011; 108(10): 4218-23. 
38. Schraders M, Haas SA, Weegerink NJ, Oostrik J, Hu H, Hoefsloot LH i wsp. Next-generation sequencing identifies mutations of SMPX, which encodes the small muscle protein, $\mathrm{X}$-linked, as a cause of progressive hearing impairment. Am J Hum Genet, 2011; 88(5): 628-34.

39. Pierce SB, Walsh T, Chisholm KM, Lee MK, Thornton AM, Fiumara A i wsp. Mutations in the DBP-deficiency protein HSD17B4 cause ovarian dysgenesis, hearing loss, and ataxia of Perrault Syndrome. Am J Hum Genet, 2010; 87(2): 282-88.

40. Pierce SB, Chisholm KM, Lynch ED, Lee MK, Walsh T, Opitz JM i wsp. Mutations in mitochondrial histidyl tRNA synthetase HARS2 cause ovarian dysgenesis and sensorineural hearing loss of Perrault syndrome. Proc Natl Acad Sci USA, 2011; 108(16): 6543-48.

41. Sirmaci A, Walsh T, Akay H, Spiliopoulos M, Sakalar YB, Hasanefendioğlu-Bayrak A i wsp. MASP1 mutations in patients with facial, umbilical, coccygeal, and auditory findings of Carnevale, Malpuech, OSA, and Michels syndromes. Am J Hum Genet, 2010; 87(5): 679-86.

42. Klein CJ, Botuyan MV, Wu Y, Ward CJ, Nicholson GA, Hammans S i wsp. Mutations in DNMT1 cause hereditary sensory neuropathy with dementia and hearing loss. Nat Genet, 2011; 43(6): 595-600.
43. McKenna A, Hanna M, Banks E, Sivachenko A, Cibulskis K, Kernytsky A i wsp. The Genome Analysis Toolkit: a MapReduce framework for analyzing next-generation DNA sequencing data. Genome Res, 2010; 20(9): 1297-303.

44. 1000 Genomes Project Consortium, Abecasis GR, Auton A, Brooks LD, DePristo MA, Durbin RM i wsp. An integrated map of genetic variation from 1,092 human genomes. Nature, 2012; 491(7422): 56-65.

45. Sherry ST, Ward MH, Kholodov M, Baker J, Phan L, Smigielski EM, i wsp. dbSNP: the NCBI database of genetic variation. Nucleic Acids Res, 2001; 29(1): 308-11.

46. Van Hauwe P, Everett LA, Coucke P, Scott DA, Kraft ML, Ris-Stalpers C i wsp. Two frequent missense mutations in Pendred syndrome. Hum Mol Genet, 1998; 7(7): 1099-104.

47. Taylor JP, Metcalfe RA, Watson PF, Weetman AP, Trembath RC. Mutations of the PDS gene, encoding pendrin, are associated with protein mislocalization and loss of iodide efflux: implications for thyroid dysfunction in Pendred syndrome. J Clin Endocrinol Metab, 2002; 87(4): 1778-84. 